\title{
Die herwinningstelling met toepassing op risikobestuur
}

\section{Outeurs:}

Vaughan van Appel ${ }^{\mathrm{a}, \mathrm{b}}$

E Maréc

\section{Affiliasies:}

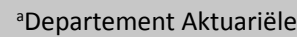
Wetenskap, Universiteit van Pretoria, Suid-Afrika 'Departement Statistiek, Universiteit Johannesburg, Suid-Afrika

'Departement Wiskunde en Toegepaste Wiskunde, Universiteit van Pretoria, Suid-Afrika

Korresponderende outeur: Vaughan van Appel E-pos: vvanappel@uj.ac.za

Hoe om hierdie artikel aan te haal:

Vaughan van Appel,

E Maré, Die herwinningstelling met toepassing op risikobestuur, SuidAfrikaanse Tydskrif vir Natuurwetenskap en Tegnologie 39(1) (2020). https://doi.org/10.36303/ SATNT.2020.39.1.830

\section{Kopiereg:}

(C) 2020. Authors

Licensee: Die SuidAfrikaanse Akademie vir Wetenskap en Kuns. Hierdie werk is onder die Creative Commons Attribution License gelisensieer.
The recovery theorem with application to risk management: The forward-looking nature of option prices provides an appealing way to extract risk measures. In this study, we extract the real-world return-density forecast, implied from option prices, using the recovery theorem and compare the predictive power of the real-world return-density forecast with the risk neutral return-density forecast by back testing.

Die vooruitblik op finansiële sekuriteitsregte is 'n aantreklike metode om bewegings in batepryse te modelleer. In hierdie studie is die vooruitskattingsverdeling uit sekuriteitsregte beraam en dan vir risikovooruitskatting gebruik. Meer spesifiek word die werklike opbrengsverdeling herwin, soos geïmpliseer deur die opsiemark, met gebruik van Ross (2015) se herwinningstelling ("recovery theorem"). Onder sekere aannames maak die toepassing van herwinningstelling dit moontlik om die kernprys en werklike opbrengsverdeling van batepryse vanuit die risikoneutrale verdeling te bepaal. Die herwinning van die werklike opbrengsverdeling behels egter die oplossing van twee swak geformuleerde probleme (Audrino et al., 2014; Kiriu en Hibiki, 2015; Spears, 2013). Om hierdie swak geformuleerde probleme te kan oplos, word 'n gereguleerde meerveranderlike mengselverdeling geïmplementeer om 'n meer akkurate beraming vir die herwinning van die werklike opbrengsverdeling te verkry (Van Appel en Maré, 2018). Die bate opbrengsverdeling is van kardinale belang in finansiële probleme, soos in risikobestuur en portefeulje-optimering. Voorts is terugwaartse toetse op die herwinde werklike opbrengsverdeling gedoen en die vooruitskattingsvermoë daarvan vergelyk met die vooruitskattingsverdeling wat volgens 'n eenvoudige historiese simulasiebenadering verkry is. 'n Empiriese studie op die Suid-Afrikaanse Top 40-indeks het bevind dat die beraming van die werklike opbrengsverdeling met die gebruik van die herwiningstelling bevredigende risikomaatreëls gelewer het.

\section{Verwysings}

Audrino F, Huitema R, Ludwig M. 2014. An Empirical Analysis of the Ross Recovery Theorem. Beskikbaar by: https://ssrn.com/ abstract $=2433170$

Kiriu T, Hibiki N. 2015. Estimating Forward Looking Distributions with the Ross Recovery Theorem. Proceedings of the Asia Pacic Industrial Engineering \& Management Systems Conference.

Ross S. 2015. The Recovery Theorem. The Journal of Finance 70(2), 615-647.

Spears TJ. 2013. On Estimating the Risk-Neutral and Real-World Probability Measures. Masters Thesis, University of Oxford. Van Appel V, Maré E. 2018. The Ross recovery theorem with a regularised multivariate markov chain. ORiON 34(2), 133-155
Nota: 'n Seleksie van referaatopsommings: Studentesimposium in die Natuurwetenskappe, 31 Oktober - 1 November 2019 , Universiteit van die Vrystaat. Reëlingskomitee: Prof Rudi Pretorius (Departement Geografie, Universiteit van Suid-Afrika); Dr Hertzog Bisset (Suid-Afrikaanse Kernenergie-korporasie; Dr Ernie Langner (Departement Chemie, Universiteit van die Vrystaat) en Dr Wynand Nel (Departement Rekenaarwetenskap en Informatika, Universiteit van die Vrystaat). 